https://doi.org/10.29013/AJT-20-3.4-39-45

Tilavov Khusan Shomurodovich, Doctoral student of Tashkent Institute of Chemical Technology

Sarsenbaev Nurlan Tenelbayuly, Master of the Tashkent Institute of Chemical Technology

Kadirov Khasan Irgashevich, Doctor of technical sciences, Professor, Tashkent Institute of Chemical Technology

E-mail: tkti.kodirov@mail.ru Baltabaev Ulugbek Narbaevich, Doctor of technical sciences $(P h D)$., associate professor, Tashkent Institute of Chemical Technology

\title{
PYRIDINE BASE SYNTHESIS CATALYSTS
}

Abstract. The aim of this work was to obtain corrosion inhibitors. It has been established that heterocyclic compounds, including pyridine and its derivatives, are used more and more often as the active component in the composition of modern corrosion inhibitors. The catalytic reaction of obtaining pyridine and its derivatives by passing a mixture of acetaldehyde and formalin with ammonia was studied. The resulting catalyst in the mixture was used as an inhibitor of hydrochloric acid treatment.

Keywords: heterocyclic compounds, pyridine, catalyst, corrosion inhibitor, acetylene, ammonia.

Introduction. The accelerated development of the oil and gas industry has an impact on scientific and technological progress in the field of engineering and technology for drilling, production, transportation and processing of oil and gas.

An increase in the number of people involved in the development of new gas, gas condensate and oil fields, the introduction of oil and gas pipelines and compressor and economic methods and technical means to prevent the occurrence of corrosion effects on borehole, field, transport equipment and pipelines. Natural gas contains highly corrosive components, such as hydrogen sulfide (1.0-5.0\% vol.) and carbon dioxide (up to $6 \%$ vol.).

The fight against corrosion of oil and gas equipment is carried out by various methods $[1 ; 2]$. However, the most widely used inhibition is one of the simplest, most effective and economically feasible methods of combating corrosion.
Corrosion inhibitors inhibit, and in some cases almost completely allow the process of destruction of metals in aggressive environments, acting as a protective coating and neutralizer.

Currently, Dodicor (Germany), Danox (Spain), Vikor, Neftekhim-3, V-2, V-3 (Russia) and others are used as a corrosion inhibitor in the Republic [3].

The procus of increasing of new substances with inhibition properties continues intensively, among which heterocyclic compounds have their own special place.

The authors of [4] studied the inhibitory capabilities of some heteroaromatic bases and their complexes with transition metal salts, as well as the development of effective corrosion inhibitors in order to protect the equipment of the petrochemical and oil-gas field complexes.

I. V. Kolobova revealed the protective effect of nitrogen-containing compounds and complexes 
with transition metal salts. Preliminary tests of the inhibitory ability of pyridines and quinolines were carried out using a Monicor-1M corrosion meter in a $5 \%$ aqueous $\mathrm{NaCl}$ solution in a three electrode cell under stirring of a corrosive medium. At the same time, it was found that 4-vinylpyridine, pyridinothiols of 2- [beta] -oxyethylpyridines in high concentrations noticeably reduces the rate of corrosion of metal St.20.

In works [5-7], universal corrosion inhibitors based on aminophenols and heterocyclic amines of the "SNPH" brand are proposed. For this, a series of functionally substituted alkyl[poly- (ethyleneoxy)] - phosphoryl pyridine, alkyl- [poly- (ethyleneoxy)] - phosphorylquinoline, aryl- [poly- (ethyleneoxy)] - phosphoryl pyridine and aryl- [poly- (ethyleneoxy) series was synthesized.) ] - phosphorylquinoline salts and systematic studies of their properties were carried out. It was found that a number of synthesized compounds have high anticorrosive properties in highly mineralized hydrogen sulfide and carbon dioxide containing aqueous media, as well as the dependence of the anticorrosive activity of the synthesized compounds on the length of the alkyl substituent in the alkyl and aryl radical, and the degree of hydroxyethylation. The dependence of the anticorrosive action of the synthesized compounds on concentration and time was studied. Using IR spectroscopy, it was shown that the phosphoryl group present in the structure of the synthesized compounds ensures the chemisorption of inhibitor molecules on the metal surface due to the formation of complex compounds with iron (II) ions. Using probe electron microscopy, it was found that the synthesized heterilonium salts form an adsorption film on the metal surface, which prevents corrosion damage. Given the high cost and the impossibility of using individual heterocyclic amines for large-scale production, the synthesis of the corresponding heterilonium salts of phosphorous acids was carried out on the basis of coke-chemical raw materi- als - the isoquinoline fraction, which is a mixture of quinoline, isoquinoline, toluidines and other heterocyclic compounds. A high degree of anticorrosion protection of the synthesized heterilonium salts of phosphorous acids is shown as corrosion inhibitors of oilfield equipment in aqueous media containing hydrogen sulfide and carbon dioxide.

An analysis of the literature on the synthesis and use of corrosion inhibitors shows that heterocyclic compounds including pyridine and its derivatives are used as the active component. The widespread use of pyridine and their derivatives is delayed due to the lack of convenient methods for their synthesis. The diverse methods available in the literature for the synthesis of heterocycles are multi-stage. In addition, the starting compounds for their synthesis are in many cases difficult to access.

Research Methods. We used chromium mass spectroscopy: an AgilentTechnology gas chromatography mass spectrometer GS6890 / MS5973N using a capillary column measuring $30 \mathrm{~m} \times 0.25 \mathrm{~mm}$ with $5 \%$ phenylmethylsiloxane in dimethylsiloxane, the carrier gas was hydrogen, and the injector temperature was $280^{\circ} \mathrm{C}$, the temperature of the MS source is $230^{\circ} \mathrm{C}$, the temperature of the MS quadrupole is $180^{\circ} \mathrm{C}$, when programming the temperature of the column thermostat from 100 to $280^{\circ} \mathrm{C}$, the temperature rise rate is $10^{\circ} \mathrm{C} \mathrm{min}$, the sample size is $1 \mu \mathrm{l}$, in the non-dividing mode, $\mathrm{X}$-ray diffraction patterns of the catalysts were taken on a DRON-2 diffractometer (radiation Cuka-copper, speed $2 \mathrm{deg} / \mathrm{min}$ ), Paulik-Paulik and Erdey derivatograph; in addition, standardized test methods and others were studied to determine the physicomechanical and technological properties.

Experimental part. Catalysts for the synthesis of heterocyclic compounds were prepared by suspending the active components with a carrier, followed by molding, drying, and calcining, some comparative characteristics of which are presented in Table 1 . As a carrier, alumina hydrate PPP-33\% was used, according to TU6.03714-78. 
Table 1.- Comparative characteristics of the used catalysts

\begin{tabular}{|c|c|c|c|c|c|c|c|c|c|}
\hline \multirow[b]{2}{*}{ No. } & \multirow{2}{*}{ 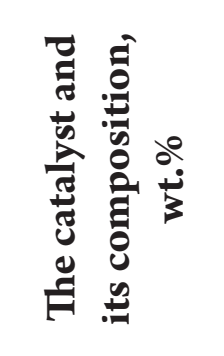 } & \multirow{2}{*}{ 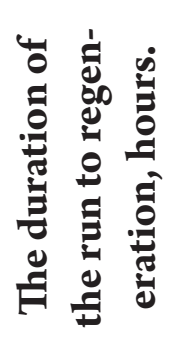 } & \multirow[b]{2}{*}{ 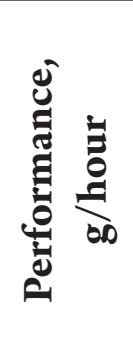 } & \multirow{2}{*}{ 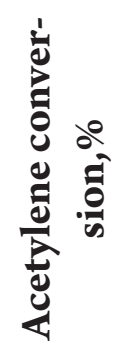 } & \multicolumn{5}{|c|}{$\begin{array}{l}\text { The composition of the organic layer of } \\
\text { catalysis }\end{array}$} \\
\hline & & & & & 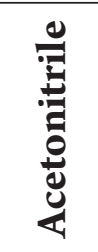 & 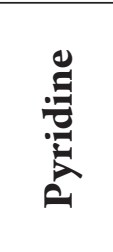 & 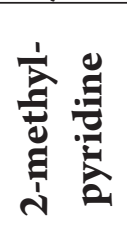 & 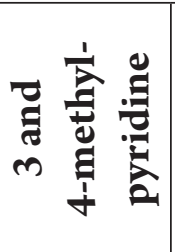 & 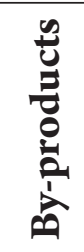 \\
\hline 1. & $\begin{array}{l}\mathrm{Cr}_{2} \mathrm{O}_{3}-20.0 \\
\mathrm{Al}_{2} \mathrm{O}_{3}-80.0\end{array}$ & 24 & 92.0 & 94.0 & 92.0 & - & traces & - & 7.0 \\
\hline 2. & $\begin{array}{l}\mathrm{ZnO}-20.0 \\
\mathrm{Al}_{2} \mathrm{O}_{3}-80.0\end{array}$ & 20 & 86.0 & 75.0 & 84.0 & - & 10.0 & 4.0 & 2.0 \\
\hline 3. & $\begin{array}{l}\mathrm{CdF}_{2}-20.0 \\
\mathrm{Al}_{2} \mathrm{O}_{3}-80.0\end{array}$ & 48 & 102.0 & 92.0 & 20.0 & - & 48.0 & 24.0 & 18.0 \\
\hline 4. & $\begin{array}{c}\mathrm{CdF}_{2}-10.0 \\
\mathrm{ZnO}_{2}-5.0 \\
\mathrm{Cr}_{2} \mathrm{O}_{3}-3.0 \\
\mathrm{Al}_{2} \mathrm{O}_{3}-82.0\end{array}$ & 72 & 114 & 90.0 & 5.0 & 35.0 & 30.0 & 25.0 & 5.0 \\
\hline 5. & $\begin{array}{c}\mathrm{CdF}_{2}-5.0 \\
\mathrm{ZnO}_{-5.0} \\
\mathrm{Cr}_{2} \mathrm{O}_{3}-5.0 \\
\mathrm{AlF}_{3}-3.0 \\
\mathrm{Al}_{2} \mathrm{O}_{3}-82.0\end{array}$ & 96.0 & 110 & 93.0 & 7.0 & - & 51.0 & 26.0 & 16.0 \\
\hline 6. & $\begin{array}{c}\mathrm{CdF}_{2}-5.0 \\
\mathrm{ZnO}-5.0 \\
\mathrm{Cr}_{2} \mathrm{O}_{3}-5.0 \\
\mathrm{Fe}_{2} \mathrm{O}_{3}-3.0 \\
\mathrm{AlF}_{3}-3.0 \\
\mathrm{Al}_{2} \mathrm{O}_{3}-78.0\end{array}$ & $\begin{array}{l}144 \\
180\end{array}$ & $\begin{array}{c}120.0 \\
135\end{array}$ & $\begin{array}{l}95.0 \\
96.0\end{array}$ & $\begin{array}{l}3.0 \\
5.0\end{array}$ & $\begin{array}{l}35.0 \\
\text { traces }\end{array}$ & $\begin{array}{l}22.0 \\
52.0\end{array}$ & $\begin{array}{c}29.0 \\
30\end{array}$ & $\begin{array}{l}11.0 \\
12.0\end{array}$ \\
\hline
\end{tabular}
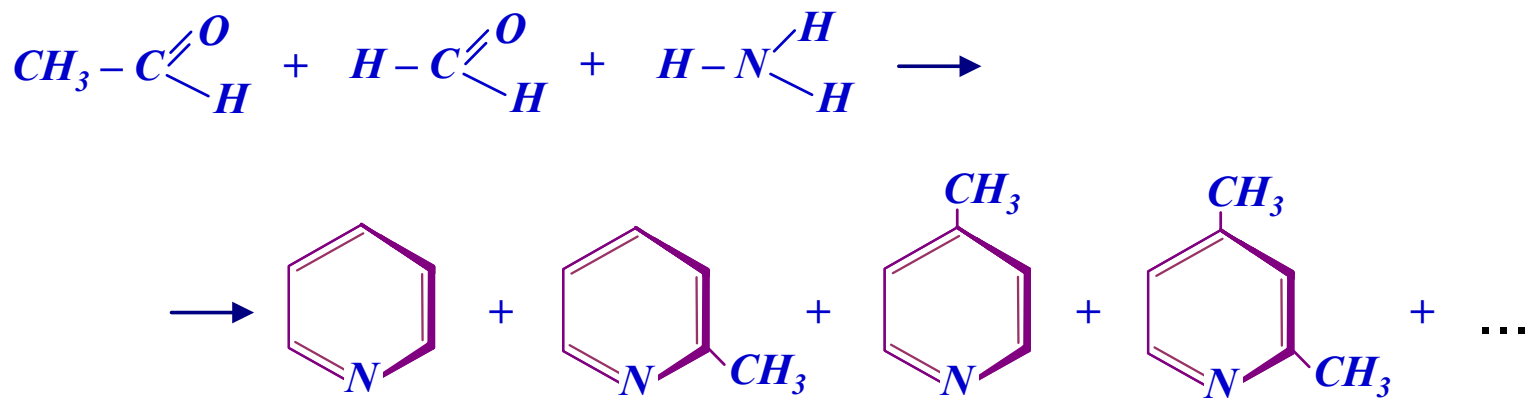

The heterocyclization of acetylene with ammonia (methanol) was carried out in a flow unit, in a stainless steel reactor with a size $\mathrm{d} \times \mathrm{l}=25-1000 \mathrm{~mm}$.

As the catalyst used catalyst № 6 .
Individual products were isolated by fractionation of catalysis on a column with 30 t.t. and identified by their physical constants.

3-methylpyridine was isolated from a mixture of 3- and 4-methylpyridines by treating the latter with 
formaldehyde, followed by steam distillation and azeotron distillation.

Results and discussion of research. The influence of the calcination temperature on the specific sur- face, productivity and conversion of catalyst No. 6 in the temperature range $450-650^{\circ} \mathrm{C}$ was studied (Table 2).

Table 2. - Effect of calcination temperature on catalyst activity

\begin{tabular}{|c|c|c|c|}
\hline $\begin{array}{c}\text { Catalyst calcination } \\
\text { temperature, }{ }^{\circ} \mathbf{C}\end{array}$ & $\begin{array}{c}\text { Specific surface } \\
\text { area, } \mathbf{~}^{\mathbf{2}} / \mathbf{r}\end{array}$ & $\begin{array}{c}\text { Productivity, } \\
\mathbf{g} / \mathbf{k g} \text { cat hour }\end{array}$ & $\begin{array}{c}\text { Acetylene } \\
\text { conversion, } \%\end{array}$ \\
\hline 450 & 182.0 & 124.0 & 92.0 \\
\hline 500 & 170.0 & 120.0 & 85.0 \\
\hline 575 & 145.0 & 92.0 & 70.0 \\
\hline 650 & 102.0 & 70.0 & 55.0 \\
\hline
\end{tabular}

As can be seen from the data (table 2), with an increase in the calcination temperature, the specific surface area and productivity of the catalyst gradually decrease, as well as the conversion of acetylene. With an increase in the calcination temperature from 450 to $650{ }^{\circ} \mathrm{C}$, the $\gamma-\mathrm{Al}_{2} \mathrm{O}_{3}$ transition to $\alpha-\mathrm{Al}_{2} \mathrm{O}_{3}$ begins and pore sizes increase, which leads to a decrease in the specific surface.

When conducting thermal analysis of catalyst No. 6 on derivatograms, 3 endo- and 2-exothermic effects are distinguished (Fig. 1):

90-140 ${ }^{\circ} \mathrm{C}$ - endothermic effect of removal of capillary and adsorbed water;

$180-220^{\circ} \mathrm{C}$ - exothermic effect of crystallization of amorphous aluminum hydroxide;

$240-290^{\circ} \mathrm{C}$ - endothermic effect of thermal decomposition of hydroxysols of aluminum, zinc and cadmium;

$310-340^{\circ} \mathrm{C}$ - exothermic effect of the onset of crystallization of aluminum oxide;

$440-460^{\circ} \mathrm{C}$ - endothermic effect of the removal of structural hydroxides from the crystal lattice of aluminum oxide and the occurrence of solid-phase reactions with the formation of solid solutions.

In connection with the studies of the thermal synthesis of catalysts, we note that, with an increase in the operating time of catalyst № 6 , a significant increase in the mechanical strength of the catalyst (by $12 \mathrm{~kg} / \mathrm{cm}^{2}$ in 200 hours) was found with a simultaneous decrease in its specific surface (from 151.6 to $97.2 \mathrm{~m}^{2} / \mathrm{g}$ ).

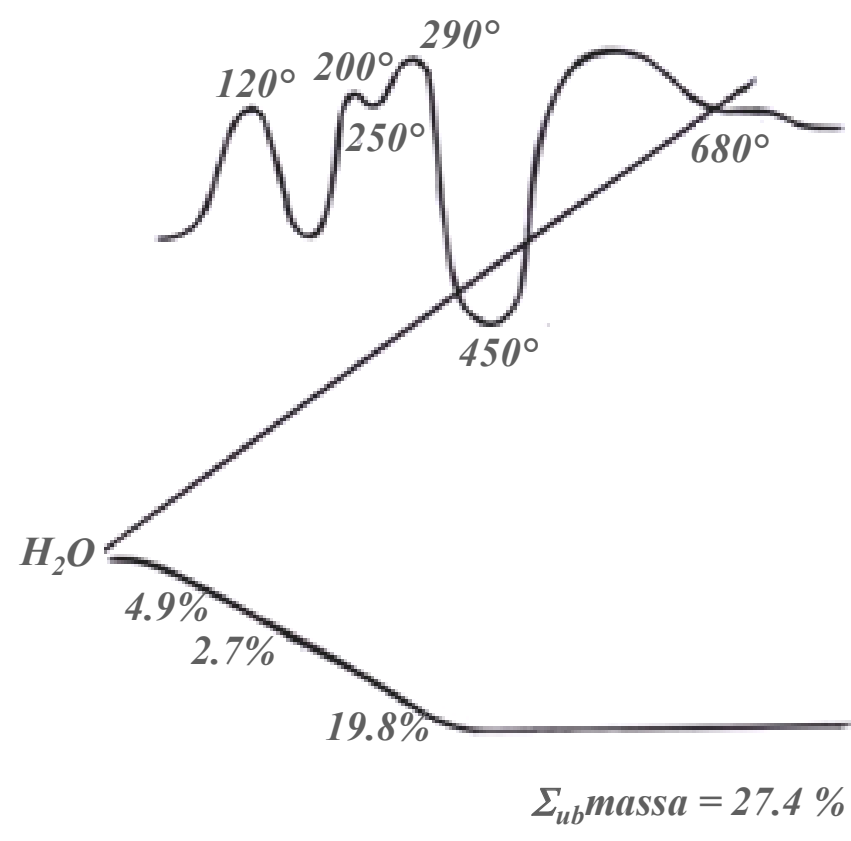

Figure 1. Catalyst Derivatogram № 6

This is most likely due to the fact that, as the operating time of the catalyst increases, a new crystalline phase is released. All investigated samples of the catalysts in the fresh state were amorphous, the formation of the crystalline phase was observed only after 150-200 hours of operation.

The study of the porous structure of the catalyst samples showed that all the studied samples are characterized by the presence of small pores in them. The pore sizes of the studied catalysts range from $40-50$, and their pore volume is in the range of $0.3-0.15 \mathrm{~cm}^{3} / \mathrm{g}$. 


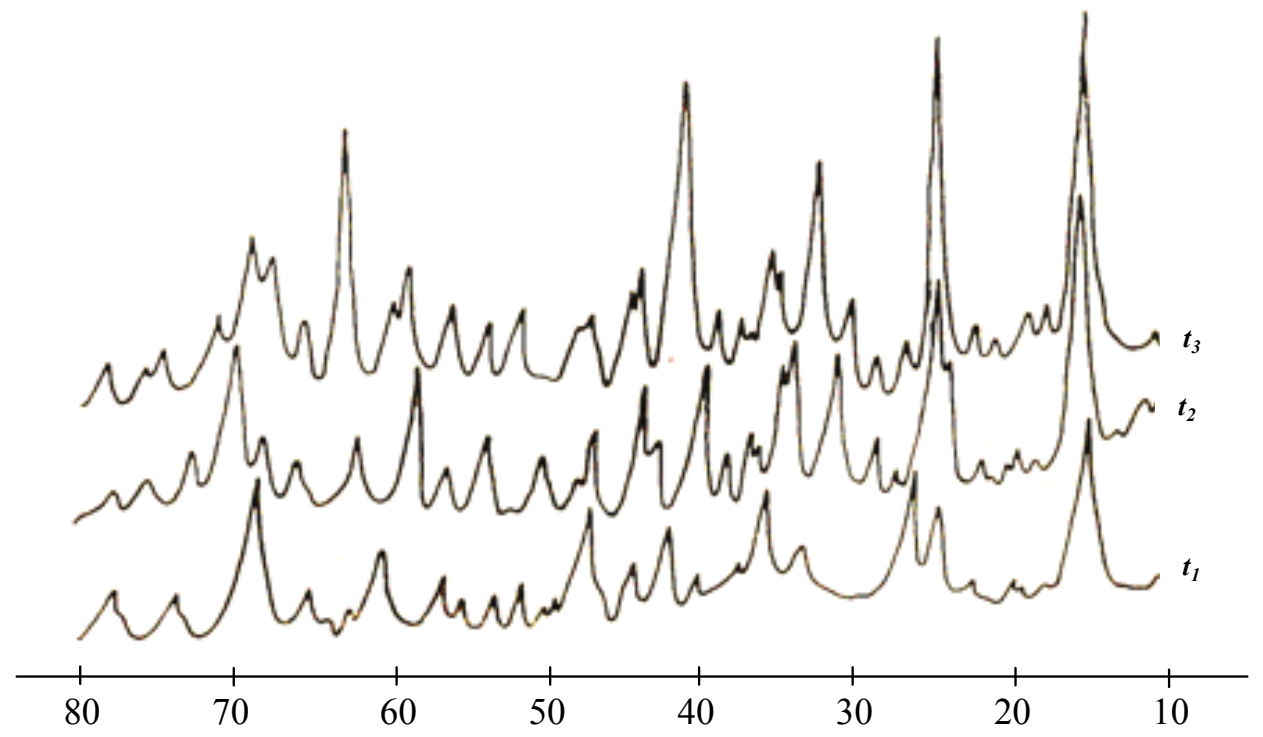

Figure 2. X-ray diffraction patterns of catalyst No. 6 calcined at various temperatures:

$$
t_{1}=500^{\circ} \mathrm{C} ; 2 . t_{2}=575^{\circ} \mathrm{C} ; 3 . t_{3}=650^{\circ} \mathrm{C}
$$

X-ray studies showed that the catalysts have a phase increases, the amount of chemically bound fairly high activity in the polyamorphic-crystalline water decreases, the decomposition of hydroxystate when chemically bound water is retained. fluorides begins, as a result of which the specific With an increase in the calcination temperature surface area of the catalyst decreases and its activity from 450 to $650^{\circ} \mathrm{C}$, the fraction of the crystalline decreases (Fig. 2).

Table 3. - Effect of inhibitor mixture concentration on corrosion rate steel St. 3 in $15 \%$ acid $\left(t=60{ }^{\circ} \mathrm{C}, \tau=4 \mathrm{~h}\right)$

\begin{tabular}{|c|c|c|}
\hline Inhibitor concentration, $\mathbf{~ m} \mathbf{~} \mathbf{l}$ & Corrosion $\mathbf{R a t e}, \mathbf{g} / \mathbf{m}^{\mathbf{3}} \cdot \mathbf{h}$ & Protective action \\
\hline No additives & 131.0 & - \\
\hline 0.2 & 6.5 & 95.0 \\
\hline 0.4 & 4.6 & 96.9 \\
\hline 0.6 & 4.0 & 98.2 \\
\hline 0.8 & 2.0 & 99.0 \\
\hline 1.0 & 1.4 & 99.5 \\
\hline 1.2 & 2.3 & 98.6 \\
\hline B-3 (reference) & 2.4 & 98.0 \\
\hline
\end{tabular}

Table 4. - The effect of temperature on the corrosion rate and the protective effect of the inhibitor during corrosion of steel St. 3 in $15 \%$ hydrochloric acid. Inhibitor's concentration is $0.8 \%$

\begin{tabular}{|c|l|c|c|}
\hline No. & \multicolumn{1}{|c|}{ Hydrochloric acid solution } & Corrosion rate $\mathbf{g} / \mathbf{m}^{\mathbf{2}} \mathbf{h}$ & Protective effect,\% \\
\hline $\mathbf{1}$ & $\mathbf{2}$ & $\mathbf{3}$ & $\mathbf{4}$ \\
\hline \multicolumn{4}{|c|}{ Room temperature. $\tau=24$ hours } \\
\hline \multirow{2}{*}{1} & No additives & 4.7 & - \\
\cline { 2 - 4 } & With inhibitor & 1.4 & 71.0 \\
\hline \multicolumn{4}{|r|}{ Temperature $40^{\circ}$ C. $\tau=4$ hours } \\
\hline
\end{tabular}




\begin{tabular}{|c|l|c|c|}
\hline $\mathbf{1}$ & $\mathbf{2}$ & $\mathbf{3}$ & $\mathbf{4}$ \\
\hline \multirow{2}{*}{2} & No additives & 46.2 & - \\
\cline { 2 - 4 } & With inhibitor & 0.5 & 99.0 \\
\hline \multicolumn{3}{|c|}{ Temperature $80^{\circ} \mathrm{C} . \tau=4$ hours } \\
\hline \multirow{2}{*}{3} & No additives & 131.0 & - \\
\cline { 2 - 4 } & With inhibitor & 2.0 & 98.0 \\
\hline \multicolumn{2}{|c|}{ Temperature $100^{\circ} \mathrm{C} . \tau=1$ hours } \\
\hline \multirow{2}{*}{4} & No additives & 1020 & - \\
\cline { 2 - 4 } & With inhibitor & 4.9 & 99.5 \\
\hline
\end{tabular}

When a mixture of acetylene (methanol) with ammonia is passed through, mainly pyridine mono derivatives (MSP-1) are formed in the catalysis, the mixture of which was tested as a corrosion inhibitor (tables 3-6).
At can be seen from the data in (table 3), the inhibitor effectively protects steel from corrosion at additive concentrations of $0.8-1.0 \%$.

Table 5. - The effect of inhibitors on steel corrosion of strength grade $D$ in a hydrogen sulfide medium. Room temperature. The concentration of hydrogen sulfide is 3.5-3.1 g/l. Medium - gas condensate: water $=1: 2$. Stirring, 72 hours

\begin{tabular}{|l|c|c|c|}
\hline \multicolumn{1}{|c|}{ Inhibitor } & $\begin{array}{c}\text { Inhibitorconcentra- } \\
\text { tion, } \mathbf{g} / \mathbf{l}\end{array}$ & $\begin{array}{c}\text { Corrosion rate } \\
\mathbf{g} / \mathbf{m}^{\mathbf{2}} \mathbf{h o u r}\end{array}$ & Degree of protection,\% \\
\hline No additives & - & 1.15 & - \\
\hline MSP-1 & 0.4 & 0.013 & 98.9 \\
\hline MSP-1 & 0.3 & 0.014 & 98.6 \\
\hline MSP-1 & 0.25 & 0.016 & 97.8 \\
\hline I-1-A (standard) & 0.4 & 0.035 & 96.9 \\
\hline
\end{tabular}

Table 6. - The effect of the MSP-1 series inhibitors on the corrosion of steel of strength grade $\mathrm{D}$ in a carbon dioxide environment $\left(P_{\mathrm{CO}_{2}}=1.0 \mathrm{MPa}\right.$ room temperature)

\begin{tabular}{|l|c|c|c|}
\hline \multicolumn{1}{|c|}{ Inhibitor } & $\begin{array}{c}\text { Inhibitor } \\
\text { concentration, } \mathbf{g} / \mathbf{1}\end{array}$ & $\begin{array}{c}\text { Corrosion rate } \\
\mathbf{g} / \mathbf{m}^{\mathbf{2}} \text { hour }\end{array}$ & Degree of protection,\% \\
\hline MSP-1 & 0.2 & 0.137 & 96.28 \\
\hline MSP-1 & 0.3 & 0.172 & 96.46 \\
\hline MSP-1 & 0.4 & 0.138 & 96.0 \\
\hline I-1-A (standard) & 0.3 & 0.121 & 97.17 \\
\hline
\end{tabular}

Conclusion. The catalytic reaction of producing pyridine and its derivatives by passing a mixture of acetylene (methanol) and ammonia was studied. The composition of the catalyst was selected, the influence of the calcination temperature on the specific surface, productivity and conversion of the catalyst was studied. It was found that with an increase in the calcination temperature from 450 to $650^{\circ} \mathrm{C}$, the
$\gamma-\mathrm{Al}_{2} \mathrm{O}_{3}$ transition to $\alpha-\mathrm{Al}_{2} \mathrm{O}_{3}$ begins and pore sizes increase, which leads to a decrease in the specific surface, the catalysts have a rather high activity in the polyamorphic-crystalline state when chemically bound water is retained.

It was found that when a mixture of acetylene (methanol) with ammonia is passed through, mainly pyridine mono derivatives are formed in the ca- 
talysis, whose protective effect upon corrosion of steel St. 3 in $15 \%$ hydrochloric acid at a concentration of $0.8 \%$ is $99.5 \%$.

\section{References:}

1. Shidota T. Jsces report jn the cost corrosion in Japan. Corcos. Manad. 2001.- No. 40.- P. 17-21.

2. Юсупов А., Турсунов М.А., Хамраев Б. Н. Разработка новых реагентов Аля добьгчи нефти и газа. Химическая технология. Контроль и управление, 2007.-No. 1.- С. 38-39.

3. Мустафив Ф. М., Быков А. И., Гумеров А. Г. и Ар. Зашита трубопроводов от коррозии.- Т. 2.- СПб.: Неара, 2007.- 708 с.

4. Колобова И.В. Гетероароматические основания и их комплексы с сомями переходных метамлов в качестве ингибиторов коррозии: дисс. ... канА.техн.наук.-Уфа, 2006.- 115 с.

5. Медведева М. А. Коррозия и зашита оборудования при переработке нефти и газа.- М: ИзА-во Нефть и газ РГУ нефти и газа, 2005.- 312 с.

6. Можаров А. В., Цыганкова А. Е., Иванов Е. С. Ингибирование углекислотной коррозии и наводороживания стали Ст 3. // Химия и хим. технология 2002.- Т. 45. Вып.6.- С. 157-162.

7. Моисеева А. С., Тур Ю. Ю., Рашевская Н. С. // Практика противокоррозионной защиты. 2002.No. 1 (23).- C. 30-41. 